Article

\title{
Co-Creation of Knowledge for Ecosystem Services Approach to Spatial Planning in the Basque Country
}

\author{
Lorena Peña*D, Beatriz Fernández de Manuel, Leire Méndez-Fernández, María Viota, \\ Ibone Ametzaga-Arregi $(\mathbb{D}$ and Miren Onaindia \\ Department of Plant Biology and Ecology, University of the Basque Country (UPV/EHU), 48940 Leioa, \\ The Basque Country, Spain; beatriz.fernandezd@ehu.eus (B.F.d.M.); leire.mendez@ehu.eus (L.M.-F.); \\ maria_viota001@ehu.eus (M.V.); ibone.ametzaga@ehu.eus (I.A.-A.); miren.onaindia@ehu.eus (M.O.) \\ * Correspondence: lorena.pena@ehu.es
}

Received: 29 May 2020; Accepted: 27 June 2020; Published: 30 June 2020

\begin{abstract}
Sustainable development has to be based on scientific knowledge, social agreements, and political decisions. This study aimed to analyse the implementation of the ecosystem services approach (ESA) in the spatial planning of the Basque Country, via the co-creation of knowledge. This paper uses a proposal for a regional green infrastructure (GI) to examine the co-creation of knowledge process. It addresses the community of practice; a process of co-creation of knowledge through workshops and meeting, SWOT (Strengths, Weaknesses, Opportunities, and Threats) analysis using an online survey, and mapping and identification of the multifunctional areas that provide ecosystem services (ES) to develop a GI. Results indicate that ESA has been included in spatial planning actions at different scales (biosphere reserve, metropolitan area, and region). This subsequently created an avenue for understanding the political necessities at play, so that scientists can develop useful tools for sustainable development. The findings also draw attention to the importance of establishing a constructive and mutually comprehensible dialogue between politicians, technical experts and scientists. For ES to be part of spatial planning, ESA has to be taken into account at the beginning of the planning process. We conclude that building bridges between science and spatial planning can help establish science-based management guidelines and tools that help enhance the sustainability of the territory.
\end{abstract}

Keywords: Basque Country; community of practice; green infrastructure; spatial planning; transdisciplinary

\section{Introduction}

The social and environmental problems that characterise the global change in the new Anthropocene era pose major challenges for the research community, decision-makers, and civil society organisations in general [1]. What is needed to rise to these challenges are solution-centred approaches and research that offer greater insight into both nature itself and the interactions that take place between nature and society.

Global change has many different causes and it is difficult to separate the effects of each. For example, in the case of land ecosystems, changes in land use constitute an important driving force that acts simultaneously with climate change to impact biodiversity and ecosystem processes [2]. This is why it is increasingly important to apply sustainable landscape management practices, particularly in highly anthropised areas.

Large-scale international research programmes recognise the need to deal with the environmental crisis from the perspective of complex adaptive systems [3], accepting the link which exists between ecosystems and human systems. One example is the socio-ecological systems approach [4]. Within this 
context, the link between ecosystem functions and human well-being is explored using the ecosystem services approach (ESA), with ecosystem services (ES) being understood as the 'benefits human populations derive, directly or indirectly, from ecosystem functions' [5] (p. 1). ES are classified as provisioning services, such as, for example, the supply of food and water, regulating services, such as flood protection, and cultural services, such as recreation [6]. The ES concept has also been interpreted as referring to the 'beneficial contributions of nature to a good quality of life for all people' since the maintenance of human well-being depends largely on them [7] (p. 1). An ESA is defined as 'a way of understanding the complex relationships between nature and humans to support decision making, with the aim of reversing the declining status of ecosystems and ensuring the sustainable use/management/conservation of resources' [8] (p. 8). ESA has four common characteristics: (1) a focus on the impacts that an ecosystem's health and status has on human well-being; (2) an awareness that ecosystem functioning underpins service provision; (3) a holistic approach which addresses the linked components of ecosystems at different scales and requires interdisciplinary collaboration from experts, stakeholders, and the public; and (4) ES are incorporated into policy and management decision making to better represent the benefits provided to humans by the natural world.

Although ESA has been increasingly recommended to inform environmental management and planning [9] and has generated a considerable amount of knowledge to support the development of sustainable landscape management policies, this knowledge has been slow to impregnate the policies themselves [10,11]. In fact, examples of the effective use of the ESA for operational management are still limited. One case is the promotion and creation of a green infrastructure (GI) in Europe proposed by the European Environmental Agency to conserve biodiversity and their associated ES [12]. GI is described as a planned network of natural and semi-natural areas that contribute to the generation of multiple ES, both in natural areas and in rural and urban regions [13]. This concept is based on the principle that nature and natural processes are deliberately integrated into spatial planning and spatial development in order to maintain and enhance the delivery of ES and therefore of ecological, sociological, and psychological benefits to human society. In European countries, for example, GI is widely recognized as a valuable approach not only for spatial planning of ecosystems, but also to land management as well as to climate and disaster risk management [12,14].

One of the main reasons for the scarce ESA implementation in spatial planning policies is the low level of engagement by key stakeholders in the development of those policies. As it has been mentioned above, ESA requires interdisciplinary collaboration from experts, stakeholders, and the public. In this context, transdisciplinary co-production of knowledge within a knowledge system could be considered a promising approach, because it focuses on real-world challenges, enables collaborations among various scientific disciplines and societal actors, and calls for self-reflectiveness [15]. Therefore, the creation of a transdisciplinary community of practice $(\mathrm{CoP})$ is vital to the implementation of the ESA in spatial planning and its corresponding policies since it facilitates constructive dialogue between scientists and non-scientists [16]. A CoP is understood to be a group of people with a common interest, whose aim is to generate and manage knowledge related to a specific field and integrate knowledge and social learning among the involved stakeholders (i.e., a knowledge system) [17]. Generally, shared roles and practices in the CoP preserve the results of social learning processes $[18,19]$. Ref. [20] defined social learning as learning that occurs when people engage one another, sharing diverse perspectives and experiences to develop a common framework of understanding and basis for joint action. Processes of social learning and the presence of informal actor platforms are of major importance when it comes to implementing and supporting integrated and socially, environmentally, and economically sustainable resource management [18]. Therefore, the CoP working methodology is based on co-learning and the co-production of knowledge aimed at generating outcomes based on the exchange of knowledge between key stakeholders. When this approach is adopted, space is enabled for open dialogue, oriented towards developing participants' capacity to learn, express their interests, and construct consensus-based results [21]. 
In the Basque Country (Spain), a highly developed region with an extremely fragmented landscape in which natural ecosystems have been sorely degraded, it is particularly important to ensure sustainable landscape management which takes ES into account. To do this, it is necessary to include the ESA in spatial planning policies. Some recent reviews have highlighted the enormous gap that still exists in the use of the ESA to inform spatial planning processes [22,23]. Thus, the aim of this study is to analyse the work carried out within a CoP to implement the ESA in the spatial planning of the Basque Country, via the co-creation of knowledge. The study explores the keys to success in the implementation of ESA in spatial planning, as well as the challenges involved in developing this process. The planning for the GI of the Basque Country using the ESA is shown as an example of the implementation of the ESA on the co-creation of knowledge within the CoP.

\section{Materials and Methods}

\subsection{Study Area}

The Basque Country is an Autonomous Community located in Northern Spain. It covers a surface area of $7200 \mathrm{~km}^{2}$ and encompasses the provinces of Bizkaia, Gipuzkoa, and Araba (Figure 1). It has a population of 2,200,000 inhabitants, of which over 50\% live in Bizkaia, which has a population density of 520 inhabitants $/ \mathrm{km}^{2}$. Geographically, the Basque Country is located on the border between the Atlantic and Mediterranean biogeographic regions. Consequently, Bizkaia and Gipuzkoa have a temperate rainy climate, with small temperature variations (mean temperature: $12.5^{\circ} \mathrm{C}$ ) and a uniform distribution of rainfall throughout the year (mean annual rainfall: $1500 \mathrm{~mm}$ ). In contrast, Araba has a more Mediterranean climate, with larger temperature variations (mean temperature: $4^{\circ} \mathrm{C}$ in winter and $20^{\circ} \mathrm{C}$ in summer), less rainfall (mean annual rainfall: $850 \mathrm{~mm}$ ), which is concentrated mainly in autumn and spring, and more frequent frosts. Differences in climate and topography have given rise to different land uses in the two regions. Thus, while timber exotic plantations cover $45 \%$ of the surface area of Bizkaia and Gipuzkoa, $26 \%$ of the land in Araba is used for intensive monoculture, with the principal crops being potatoes, cereal, and vines [24]. The result of this is a highly fragmented landscape in which natural ecosystems cover only a small percentage of their potential habitat.

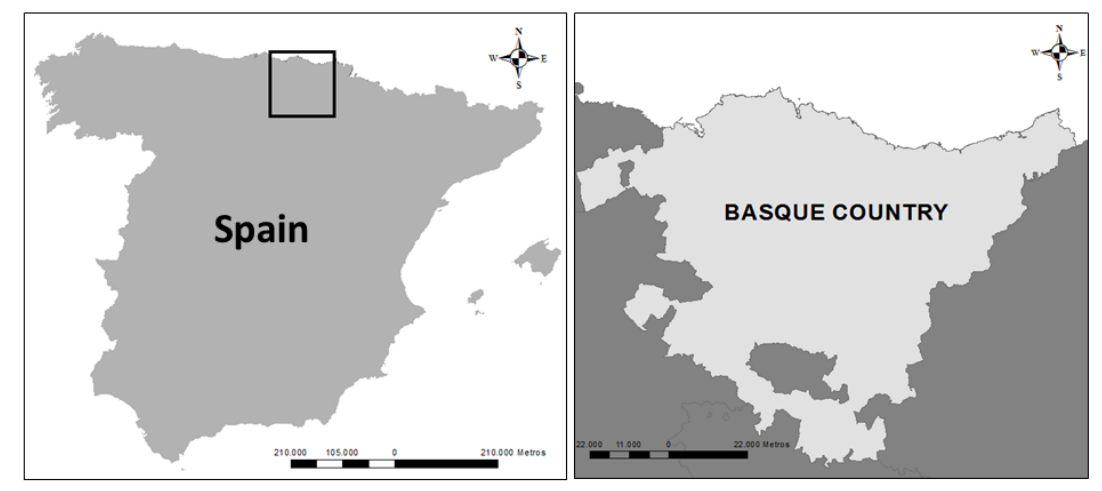

Figure 1. Location of the Basque Country (Spain).

\subsection{Creation of a Community of Practice for Implementing the ESA in Spatial Planning}

In 2013, a transdisciplinary CoP involving politicians, technical experts and scientists was set up within a project entitled Assessment of the Ecosystem Services of the Basque Country. The aim was to combine the scientific, political, technical, and social perspectives in order to obtain scientific knowledge that would be useful for conservation and sustainable landscape management policies $[25,26]$. This CoP is coordinated by the UNESCO Chair on Sustainable Development and Environmental Education at the University of the Basque Country (UPV/EHU) and is made up of researchers from the UPV/EHU, technical and political staff from the public administrations (Regional Basque Government, provincial councils and local councils) and associations (Non-Governmental Organizations (NGOs)and businesses, 
etc.). The size and composition of the CoP has varied over the years, depending on the availability of and interest expressed by the different public administration departments (see Appendix A). To date, around 60 technical and scientific experts and 5 politicians have participated.

\subsection{Knowledge Co-Creation Process Assessment}

The working process of the CoP comprises systematic annual meetings with key stakeholders (average of 6 annual meetings), as well as open workshops targeted at other interested stakeholders (average of 2 annual workshops) (see Appendix A). These meetings and workshops follow the outline proposed for transdisciplinary knowledge systems, which comprises five phases: mobilise, translate, negotiate, synthesise, and apply [27] (see Figure 2). These five stages formed the basis for examining the knowledge co-creation process in the ESA in the Basque Country. To mobilise means to bring out the knowledge contributed by the different knowledge systems/stakeholders into a form that can be shared. In this case, the knowledge about the role of ES in the Basque Country for human well-being, the applicability of ESA for spatial planning, and the information available and indicators for mapping the ES, tools and guidelines, among others, were shared by the different stakeholders in workshops and meetings. To translate implies making the information understandable to the different knowledge systems, to enable mutual comprehension. In this case, the use of language, concepts and approach that are familiar and easy to understand by all stakeholders. To negotiate means establishing convergences between the different types of knowledge in relation to the shared goal, although in the event of conflicts some divergences may remain. In this case, the aim was clear, the incorporation of the ESA into the spatial planning. Thus, different management plans were proposed and analysed for the incorporation of ESA. To synthesise is to establish a common knowledge, even though the integrity of each knowledge system is maintained. Scientifics helped by technicians and politics developed maps, tools, and guides for the ESA implementation. To apply is the final phase, in which the knowledge generated is rendered usable for decision-making for all stakeholders involved. ESA was incorporated into management plans at different levels.

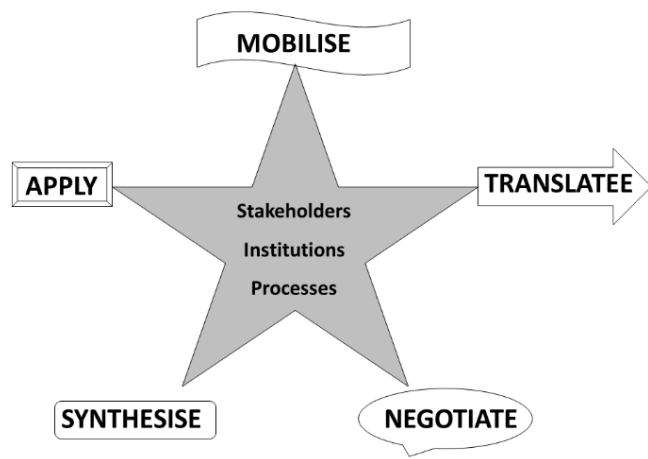

Figure 2. Operational outline for transdisciplinary knowledge systems that encompasses five phases: mobilise, translate, negotiate, synthesise, and apply (own elaboration based on [18]).

Finally, to analyse the strengths, weaknesses, opportunities, and threats of the integration of ESA in spatial planning according to the stakeholders, 10 technical experts working at the Bizkaia Provincial Council were asked to complete SWOT (Strengths, Weaknesses, Opportunities, and Threats) matrices. From this exercise, 22 statements were extracted in connection to the integration of ES in spatial planning (Appendix B). These statements were assessed by 115 people working in some capacity in the environmental field by means of an online survey, in which respondents were asked to rate the extent to which they agreed or disagreed with each statement on a scale of 1 to 5 ( $1=$ totally disagree, $5=$ totally agree). The survey was carried out in March 2019; $59 \%$ of respondents were men and $52 \%$ were aged 50 years or over. The data were analysed using the Mann-Whitney $U$ test and the Kruskal-Wallis test. 


\subsection{Proposal for a Regional Green Infrastructure Using the ESA}

To identify the components that may form part of a GI, it is first necessary to identify the multifunctional areas that provide ES. To this end, first of all, within the CoP, the priority regulating ES were identified (habitat maintenance, air purification, carbon storage, water flow regulation, and pollination) [28]. Subsequently, their spatial distributions were mapped (very high, high, medium, low and very low) in accordance with the methodology outlined in $[29,30]$, and the maps of these ES were overlaid. Those areas that had high or very high values for all ES were identified as principal components, and those with high or very high values for four of them were identified as secondary components [31]. The indicators used to map ES and the methodology for their calculation are shown in Table 1.

Table 1. Indicators used to map ecosystem services (ES) in the Basque Country and the methodology used to calculate them.

\begin{tabular}{|c|c|c|}
\hline SERVICES & PROXIES & METHODS \\
\hline $\begin{array}{l}\text { Food production } \\
\text { (agriculture and } \\
\text { livestock farming) }\end{array}$ & $\begin{array}{l}\text { Mean human food yield } \\
\text { (agriculture (AY) and } \\
\text { livestock farming (LFY)) }\end{array}$ & $\begin{array}{l}\text { AY = Mean agricultural yield of crops used to produce food for humans }(t / h a) \\
\text { LFY = Mean yield from slaughtered livestock }(t / h a)\end{array}$ \\
\hline Timber production & $\begin{array}{l}\text { Annual growth of } \\
\text { timber-producing forest } \\
\text { ecosystems }\end{array}$ & $\begin{array}{l}\text { Annual growth }\left(\mathrm{m}^{3} \text { year }^{-1} \mathrm{ha}^{-1} \text { ) obtained using LIDAR (Laser Imaging Detection and }\right. \\
\text { Ranging) } 2008 \text { and 2012, calculated by HAZI }\end{array}$ \\
\hline Habitat maintenance & $\begin{array}{l}\text { Habitat maintenance } \\
\text { index }\end{array}$ & $\begin{array}{l}\mathbf{H M}=\mathbf{W}+\mathbf{S}+\mathbf{P} \\
\mathrm{HM}=\text { Habitat maintenance index } \\
W=\text { Native vascular plant species richness } \\
\mathrm{S}=\text { Successional state } \\
\mathrm{P}=\text { Protected areas or areas of natural interest }\end{array}$ \\
\hline Carbon storage & Total carbon $(\mathrm{C})$ content & $\begin{array}{l}\text { TC }=\text { CLB }+ \text { CDB }+ \text { CS } \\
\mathrm{TC}=\text { Total } C \text { content }(\mathrm{tC} / \mathrm{ha}) \\
\mathrm{CLB}=\mathrm{C} \text { content in live biomass }(\mathrm{tC} / \mathrm{ha}) \\
\mathrm{CDB}=\mathrm{C} \text { content in dead biomass }(\mathrm{tC} / \mathrm{ha}) \\
\mathrm{CS}=\mathrm{TC} \text { content in the soil }(\mathrm{tC} / \mathrm{ha})\end{array}$ \\
\hline Air purification & $\begin{array}{l}\text { Capacity to eliminate } \\
\mathrm{NO}_{2} \text { from the air }\end{array}$ & 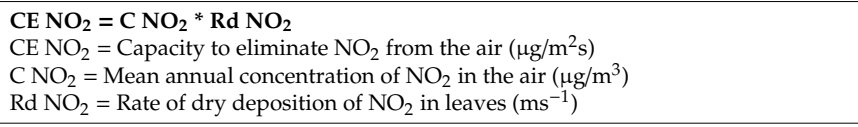 \\
\hline Water flow regulation & Water retention index & $\begin{array}{l}\text { WRI }=\left(\mathbf{W}_{\mathbf{R v}} \mathbf{R}_{\mathbf{v}}+\mathbf{W}_{\mathbf{R g w}} \mathbf{R}_{\mathbf{g w}}+\mathbf{W}_{\mathbf{R s}} \mathbf{R}_{\mathbf{s}}+\mathbf{W}_{\text {slope }} \text { Slope }+\mathbf{W}_{\mathrm{WB}} \mathbf{R}_{\mathrm{WB}}\right) *\left(\mathbf{1}-\mathbf{R}_{\mathbf{a}} / \mathbf{1 0 0}\right) \\
\text { WRI = Water retention index } \\
\text { WRv, WRgw, WRs, Wslope, WWB = Weights assigned to each variable } \\
\mathrm{Rv}=\text { Retention by vegetation } \\
\text { Rgw = Retention in ground water } \\
\text { Rs = Retention in soil } \\
\mathrm{R}_{\mathrm{WB}}=\text { Retention in water bodies } \\
\mathrm{Ra}=\text { Soil waterproofing }\end{array}$ \\
\hline Pollination & $\begin{array}{l}\text { Index of abundance of } \\
\text { nesting pollinators }\end{array}$ & Pollination module from the InVEST program \\
\hline Recreation & Recreation index & $\begin{array}{l}\mathbf{R}=\mathbf{P R}+\mathbf{C R} \\
R=\text { Recreation index } \\
P R=\text { Potential for recreation } \\
C R=\text { Capacity for recreation } \\
\mathbf{P R}=\mathbf{N}+\mathbf{P}+\mathbf{A}+\mathbf{G}+\mathbf{R} \\
N=\text { Naturalness index } \\
\mathrm{P}=\text { Level of protection } \\
A=\text { Presence of surface water bodies (rivers, lakes, transitional waters, coastal waters } \\
\text { and reservoirs) } \\
G=\text { Geological heritage of interest to tourists } \\
R=\text { Presence of summits (mountains) } \\
C R=A+I \\
A=\text { Accessibility } \\
I=\text { Presence of artificial infrastructures (recreational areas, wine cellars, museums, } \\
\text { theme parks, environmental parks, provincial parks, visitors' centres, thematic centres } \\
\text { and Mountain Bike centres), natural infrastructures (caves and rock-climbing areas), } \\
\text { natural landmarks and bird-watching posts }\end{array}$ \\
\hline $\begin{array}{l}\text { Aesthetic value of the } \\
\text { landscape }\end{array}$ & $\begin{array}{l}\text { Aesthetic value of the } \\
\text { landscape }\end{array}$ & $\begin{array}{l}\text { AL }=\mathbf{P}+\mathbf{R}+\mathbf{L a}+\mathbf{A}+\mathbf{L M}-\mathbf{N E} \\
\mathrm{AL}=\text { Aesthetic landscape index } \\
\mathrm{P}=\text { Society's perceptions } \\
\mathrm{R}=\text { Type of relief } \\
\mathrm{La}=\text { Diversity of landscapes } \\
\mathrm{A}=\text { Presence of surface water bodies } \\
\mathrm{LM}=\text { Influence of natural landmarks } \\
\mathrm{NE}=\text { Influence of negative elements }\end{array}$ \\
\hline
\end{tabular}


The software used for geoprocessing was ArcMap 10.3 [32] and the land use categories employed to assess the ES were those featured on the EUNIS map of the European Nature Information System, at a scale of 1:10,000 [24]. All ES were assigned to one of five categories: very high, high, medium, low, and very low/no contribution. These categories were defined using the Jenks natural breaks classification method [33,34].

\section{Results}

\subsection{Outcomes of Knowledge Co-Creation Process}

The co-creation of knowledge within the CoP achieved the following key milestones, ordered chronologically: (1) a multifunctional regional indicator (MESLI) based on ES at a municipal level [35]; (2) a methodological guidelines for mapping ES in the Basque Country [36]; (3) mapping the ES of the Basque Country (food production, timber production, habitat maintenance, air purification, carbon storage, water flow regulation, pollination, recreation, and aesthetic value of the landscape) (see Figure 3) [36,37]; and (4) a practical guide to formulating spatial and urban planning programmes using the ESA. The aim of this guide is to provide local and regional administrations with a clear, coherent set of technical, methodological, and conceptual guidelines to help them formulate spatial and urban planning programs, incorporating the ESA right from the initial stages of development. The guide is designed as a working tool targeted mainly at technical experts working in public administrations, sub-provincial associations, consortia, and representatives from the private sector (environmental consultants and architecture or planning studios, etc.), academia (universities and technology centres), and the social field (NGOs and environmental associations) [36].

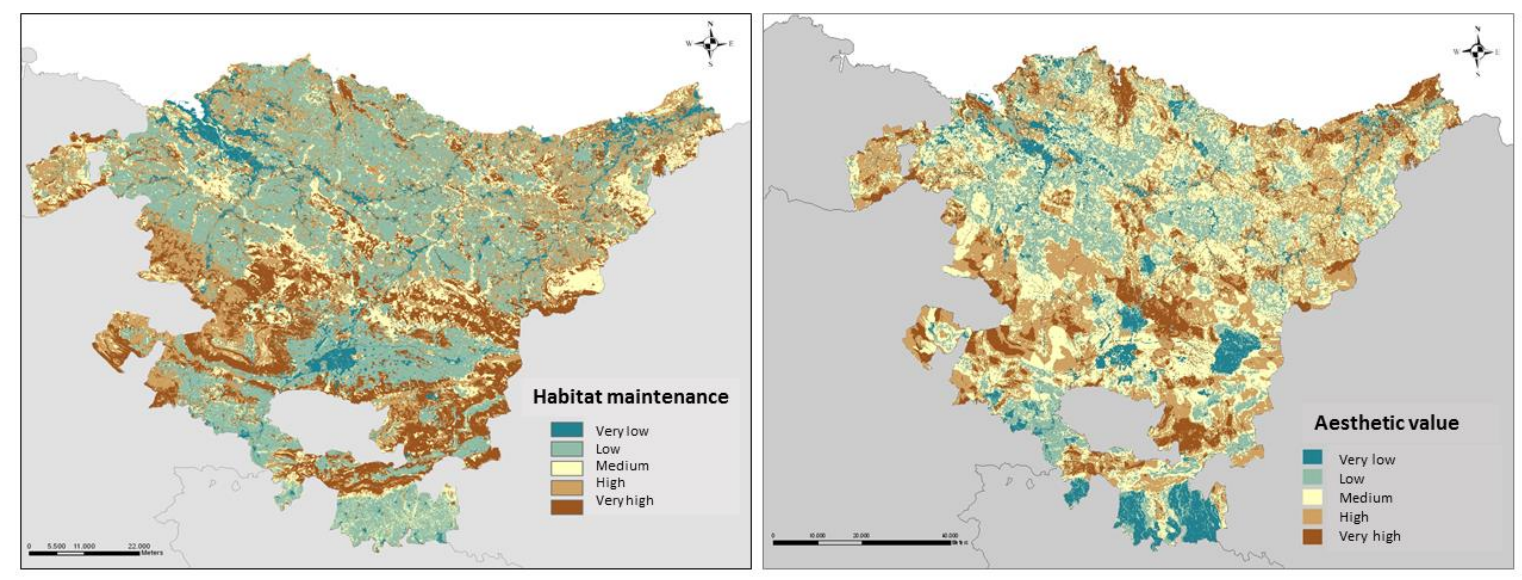

Figure 3. Maps of habitat maintenance and aesthetic value services in the Basque Country.

\subsection{Application of Knowledge Co-Creation Outcomes}

ESA has been included in spatial planning actions at different levels. For example, ESA was used: (1) to establish criteria for the Renewed Uses and Management Master Plan (UMMP) for the Urdaibai Biosphere Reserve [38,39]. Appendix I of the UMMP explains that the services provided by ecosystems in the Urdaibai Biosphere Reserve will be identified [40]; (2) to establish criteria for the Renewed Partial Territorial Plan (PTP) for the Bilbao Metropolitan Area. The ES map was included, along with a GI proposal for the Bilbao Metropolitan Area [29] in the diagnosis carried out for the revised PTP [41]; (3) to identify the components that may form part of the GI of the Basque Country (Figure 4). The principal components corresponded mainly to natural forests, and the secondary ones to pastureland, scrubland, and heaths; and (4) to include ES and GI in the Renewed Spatial Planning Guidelines (SPGs) of the Basque Country approved in 2019 (Decree 128/2019, of 30 July) [42]. The contributions made are mainly linked to terminology and the methodology used to assess ES in the Basque Country, which was included as an Appendix to the SPGs in the form of a method sheet. 
One direct consequence of the approval of the SPGs is that the different departments of the public administration now have the obligation to implement actions at different scales to promote a local GI.

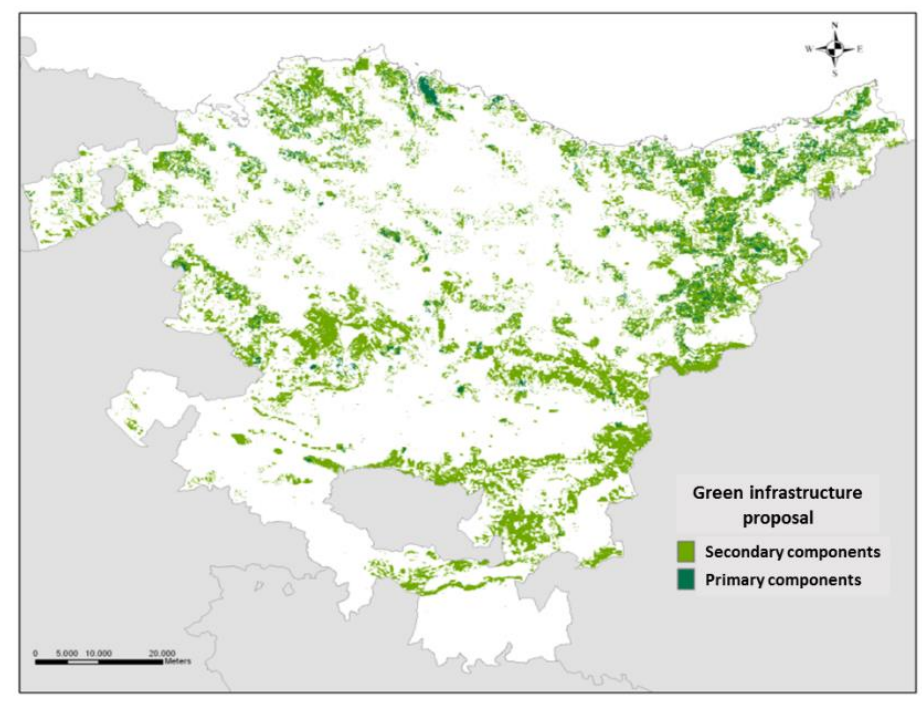

Figure 4. Map of the green infrastructure (GI) proposal in the Basque Country, based on ES.

\subsection{SWOT Analysis of the Knowledge Co-Creation Process}

The results of the survey indicated that the statements with which respondents agreed most were that budgetary cutbacks may hamper the integration of ES into landscape management and that ES are not currently a priority on the political agenda, due to a lack of awareness among political and economic authorities (Figures 5 and 6). Respondents disagreed most with statements linked to the ES concept itself and the way it is disseminated since they considered that even though it is not a difficult concept to adapt to the public discourse, it does need to be expressed using language and terms that can more easily be understood by the general public (Figures 5 and 6).

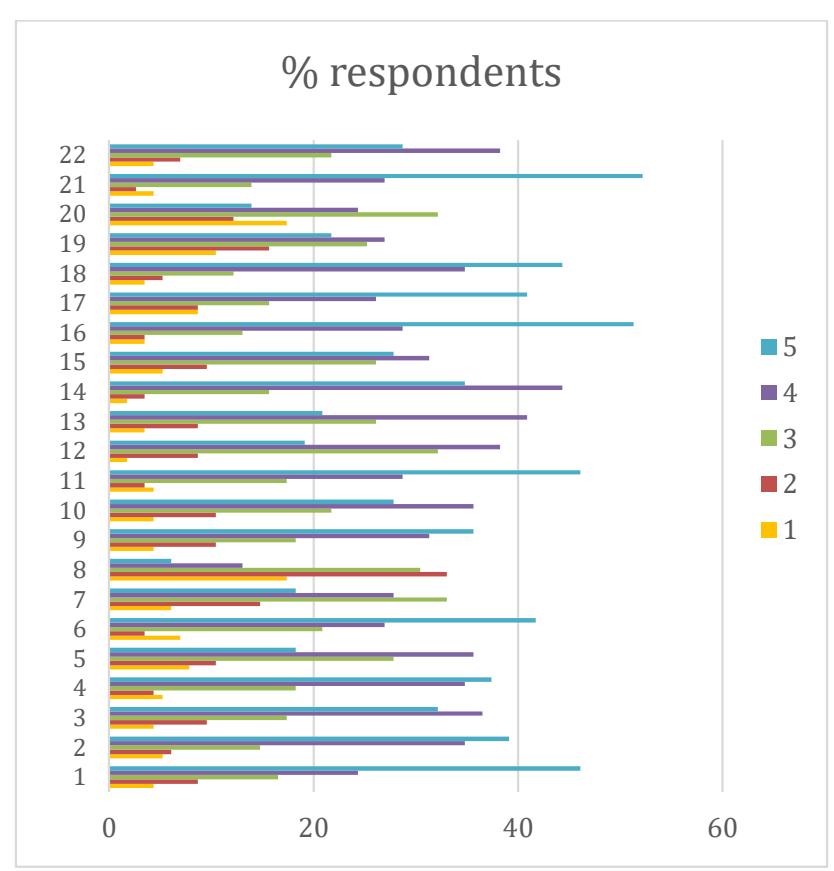

Figure 5. Graphic representation of how respondents rated each statement in percentage (\%) (1: totally disagree, 5: totally agree). The 22 statements are shown in Appendix B. 


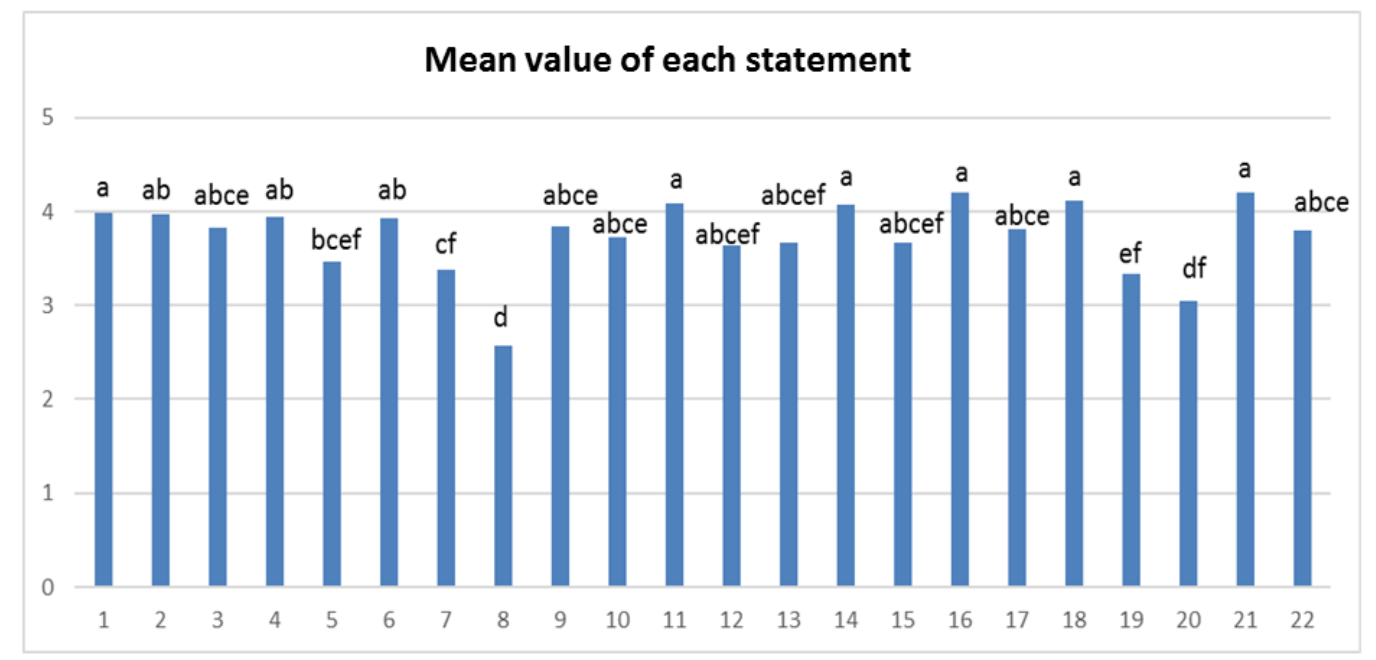

Figure 6. Graphic representation of the mean values obtained for each statement. Same letters indicate the absence of significant differences ( $p<0.05$; Kruskal Wallis test with the Bonferroni correction). The 22 statements are shown in Appendix B.

\section{Discussion}

\subsection{A New Approach to Sustainable Spatial Planning}

The ESA was applied for the first time to strengthen nature conservation policies within the framework of the EU Convention on Biological Diversity and the EU Biodiversity Strategy 2020. Nevertheless, mapping and assessment of ES, which is required by Action 5 of this strategy, is not only important for achieving biodiversity targets; it is also strongly linked to the implementation of other related policies [43]. The ESA provides an ideal comprehensive framework for facilitating planning and development decisions in all sectors, at all scales, and across administrative boundaries $[44,45]$. Thus, assessing and mapping ES are key requirements for implementing the ESA in decision-making processes, particularly in relation to sustainable spatial planning and landscape management, and the development of GI. In this sense, a map of priority ES has been compiled in the Basque Country, along with a methodological guide for mapping. Both have subsequently been used for spatial planning purposes, as in the case of the Basque SPGs approved in 2019. Article 4 of the SPGs establishes a series of guidelines for GI and ES, defining the elements that make up a GI and its characteristics. The article highlights the fact that the infrastructure of this kind should check the loss of biodiversity and mitigate the effects of spatial fragmentation, with the aim of strengthening the services offered by nature. The article also states that the ES assessment should contain information about their scope and condition, the services they provide, and their value.

The concept of GI was incorporated into Spanish law in Act 33/2015, of 21 September, modifying Act 42/2007, of 13 December, on Natural Heritage and Biodiversity. This Act stipulated that the Ministry for the Environmental Transition with the collaboration of the Autonomous Communities and other Ministries involved in some way would develop, within the maximum period of three years, a National Strategy for GI, Connectivity, and Environmental Restoration. The text of this national strategy states that the conservation of GIs is crucial to ensuring environmental connectivity, the functionality of ecosystems, the mitigation of and adaptation to climate change, the defragmentation of strategic areas, and the restoration of degraded ecosystems. Therefore, identifying, promoting, and preserving GI has the potential to provide a wide range of environmental, economic, and social benefits [46]. The regional governments in Spain play a key role in the implementation of an effective GI based on scientific/technical approaches designed to support sustainable spatial planning and landscape management policies under the umbrella of the ESA. This has been carried out in the Basque Country, in collaboration with a CoP constituted for this very purpose and made up of scientists, technical 
experts, and politicians. The methodology presented in this study on the use of a CoP for integrating the ESA into spatial planning may constitute a useful tool for spatial planning managers/decision-makers worldwide. In the case of the Basque Country, it has enabled the implementation of the ESA in the spatial planning of a Biosphere Reserve (Urdaibai UMMP), a metropolitan area (Bilbao Metropolitan Area PTP), and at a regional scale (Basque Country SPGs approved in 2019).

\subsection{Lesson Learned: Challenges for Policy Implementation and Key Success Factors}

Several important lessons were learned during this process, including the need for scientists, technical experts, and politicians to work together to implement the ESA in spatial planning and its related policies. It is also important to understand the political necessities at play, so that scientists can develop useful tools for the sustainable management of the region at different scales. Moreover, it is vital to establish a constructive and mutually comprehensible dialogue between both parts (science and politics) within a CoP designed to aid the co-creation of knowledge. ES need to be a priority on the political agenda and funds must be earmarked in the budget to integrate them into spatial planning, as well as to enable scientists to have access to useful information for developing effective tools for technical experts and politicians. The ESA should be taken into account right at the beginning of the planning process [45], and transdisciplinarity is vital in the $\mathrm{CoP}$ in order to enable different perspectives to be analysed in relation to a shared goal. Finally, it is important to develop guidelines for technical experts and politicians, to help them implement the ESA at different scales. Other authors have also highlighted the lack of institutional guidelines at different planning and administrative levels for incorporating the ESA into spatial planning processes [47].

The linking of knowledge systems requires a learning process across key aspects of the system and procedures [27], which needs a change of paradigm and usually presents difficulties. Science-policy deals such as the Inter-governmental Platform on Biodiversity and Ecosystem Services (IPBES) acknowledge the importance of support a diversity of knowledge systems to inform decision-making [48]. In this framework, there is a recognition that different approaches have to be adapted depending on the particular contexts of different knowledge systems [49]. Moreover, a transparent participatory approach is required to facilitate implementation of results [50]. In the study case, some challenges appear to be key factors of limiting successful results, and these were analysed and managed in different ways throughout the developed activities of the CoP.

An important challenge highlighted by managers in the studied situation was the difficulty for managers and stakeholders to understand the language and terms used by scientist and researchers on ESA. In this sense, it would be a necessary approach to use easy terms that would be definitely understood by the public, as proposed by other authors [51]. At the beginning of the process, the terms used when working in the CoP were in relation to the full set of benefits from ecosystems, without explicitly referencing ES. The more technical and specific terms about ESA were introduced incrementally, facilitating a shared language.

Likewise, adoption of policies and management objectives in planning based on ESA require, not only a policy-relevant research [52], but also a vision and a strong commitment from decision-makers [53]. In the case of the Basque Country, managers considered a lack of awareness among political and economic authorities as a big challenge for a successful implementation of the ESA in management. One of the most important efforts of the developed CoP was to explain the benefits of the ESA approach, and explain that it does not imply eliminating other previous methodologies, but rather complementing them. This was a good way to overcome system reluctance and fight the inertia of the system (business as usual), as even the awareness of the authorities is still a question to be solved progressively.

Moreover, budgetary cutbacks appear to be one of the most important factors that hamper the integration of ES into management in the study case, probably due to the lack of awareness of authorities. This situation has been recognised as a critical component for success by previous practitioners and managers, such as the US Forest Service [51]. This is not easy to overcome, but the 
way to improve this aspect is in relation with the previous ones, adopting an understandable language, and a transdisciplinary knowledge thorough a $\mathrm{CoP}$ is a factor to success.

\subsection{A New Paradigm for Science: Sustainability}

Given the current global crisis, we need to define a new way of creating knowledge for sustainability. Since the first definition of sustainable development in the Brundtland Report of 1987, the term has been understood to refer to the need for economic and social development in balance with nature conservation, which does not lead to the depletion of natural resources. It took 20 years for the idea to give rise to a new kind of science capable of bringing together the knowledge and methods of many different disciplines within the framework of a new conceptual and practical concept [54]. Thus, it was with the turn of the new millennium that Sustainability Science became the focus of intense interest, representing as it did the scientific collaboration between different researchers and research centres [55]. In recent years, there has been a growing shift towards a more transformational outlook based on biospheres [27], and oriented towards solving real problems and bringing about a specific change [56].

However, in order to really move towards scenarios of true sustainability, much more than science and solution-oriented sustainability research is required. There is still a scarcity of both capacity and willingness in academic, governmental and private organisations, both profit-making and non-profit NGOs, to use scientific findings in knowledge-generating operations [57]. Consequently, the development of the ESA and its transdisciplinary nature (a collaboration between all social stakeholders) may prove vital on the road to sustainability.

To build social, economic, and environmental resilience, knowledge needs to be embedded in an institutional context that enables its application, as well as in a desire to learn from the experience over time [58]. In this context, the university has a key role to play in connecting science to practice and developing outlooks involving social engagement [59].

\section{Conclusions}

The results presented here indicate that the bridges between science and management may be successful in establishing science-based decision-making/management guidelines. One of the conditions required to implement research findings is a collaboration between researchers, managers, and decision-makers, which in turn facilitates knowledge exchange, the generation of shared understanding, and the application of the results.

In this case, the ESA has been incorporated into the spatial planning of the Basque Country at different levels: in the Urdaibai Biosphere Reserve UMMP, the diagnosis for the review of the Bilbao Metropolitan Area PTP, and the renewed version of the Basque Country SPGs, which also has implications at lower scales. The CoP has made it possible for scientists, with the aid of technical experts, to provide local administrations with key tools for ensuring the sustainable management of the region.

Author Contributions: Conceptualization, L.P. and M.O.; methodology, L.P., B.F.d.M. and M.O.; software, B.F.d.M.; writing-original draft preparation, L.P. and M.O.; writing—review and editing, L.M.-F., M.V. and I.A.-A.; funding acquisition, I.A.-A. and M.O. All authors have read and agreed to the published version of the manuscript.

Funding: This research was funded by the Department of Environment, Territorial Planning and Housing of the Basque Government, and by the Department of Sustainability and Natural Environment of the County Council of Biscay.

Acknowledgments: We gratefully acknowledge the participation of the different stakeholders who have participated in the community of practice.

Conflicts of Interest: The authors declare no conflict of interest. 


\section{Appendix A Overview of the Activities Carried out by the Community of Practice}

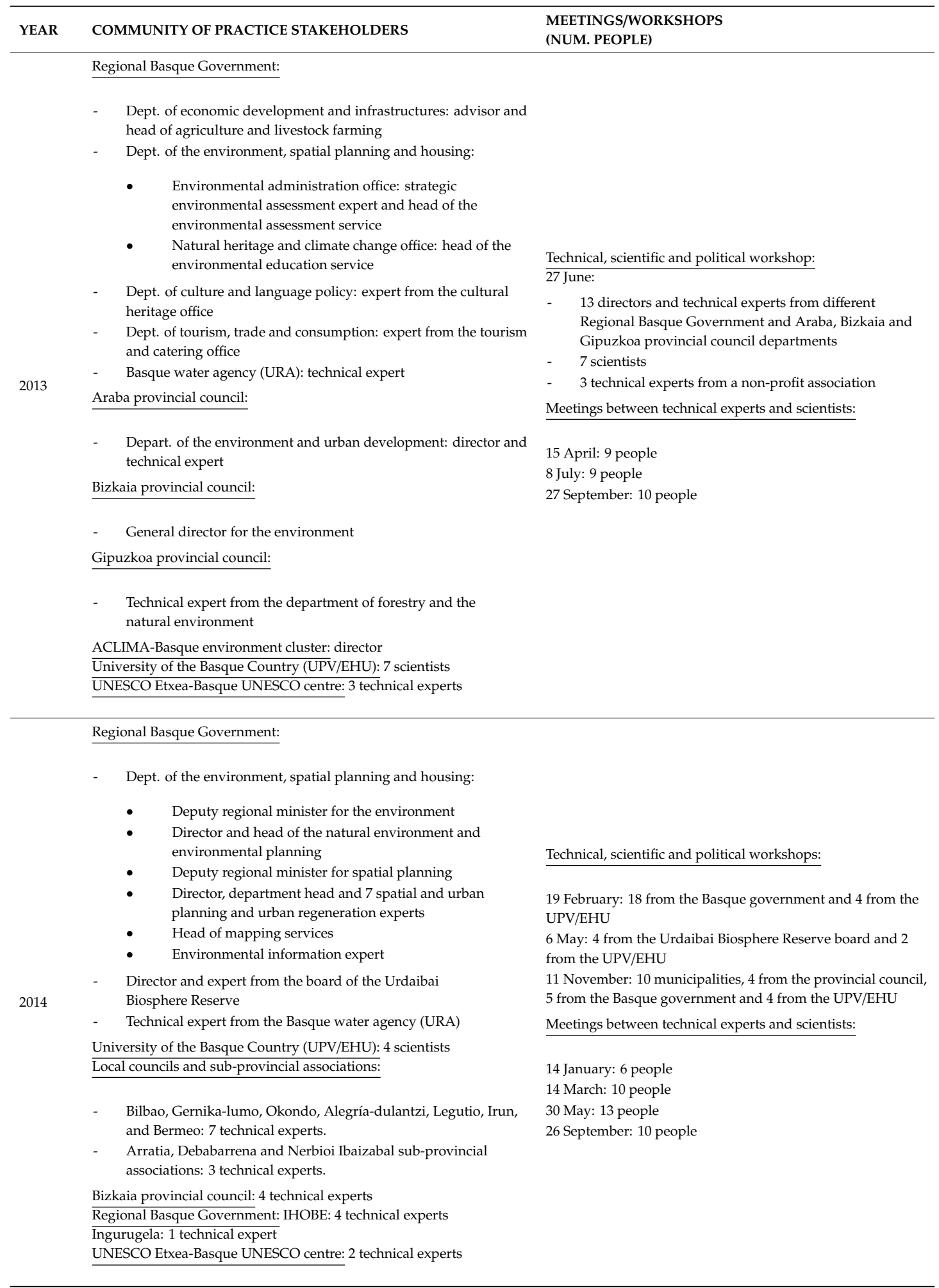




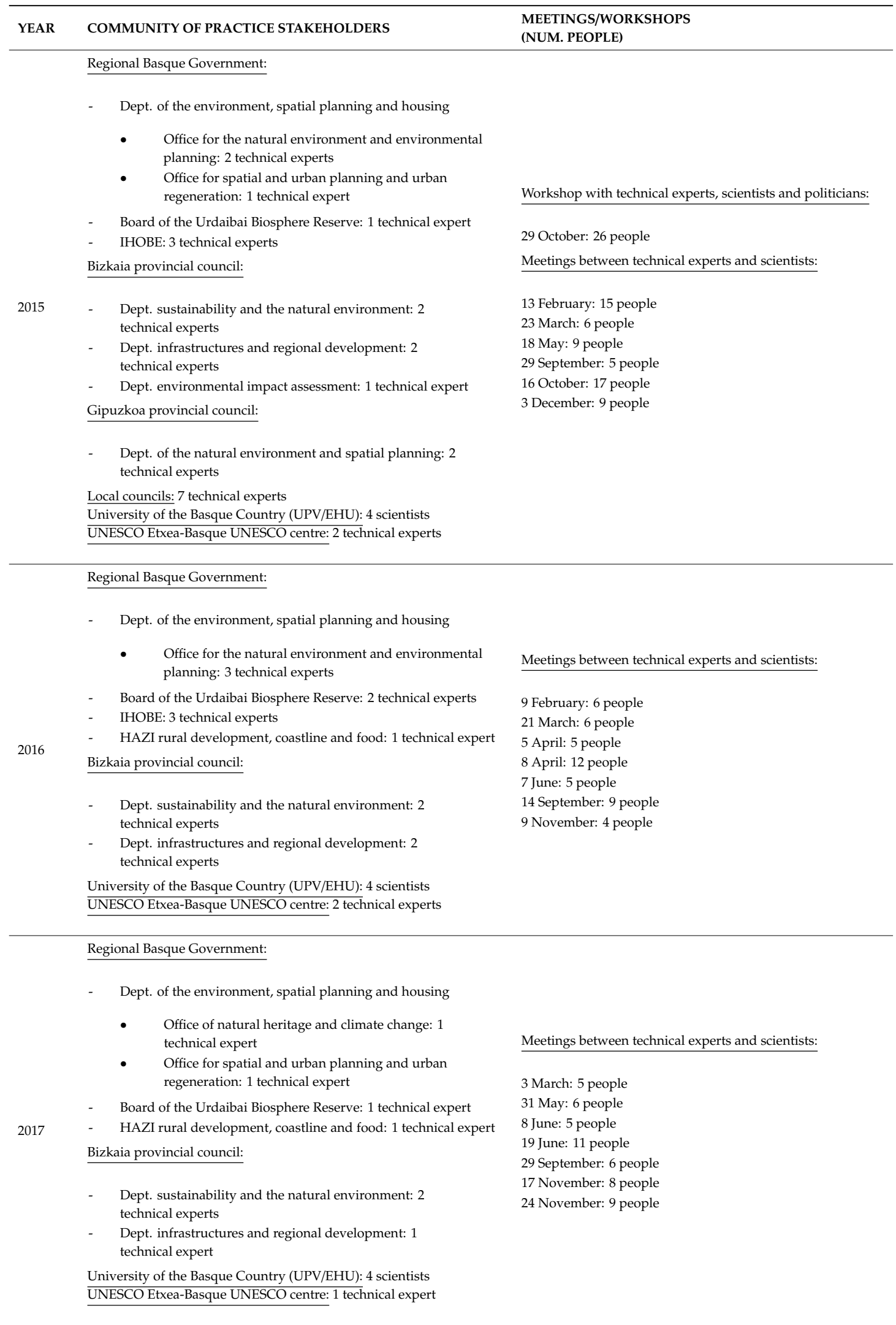




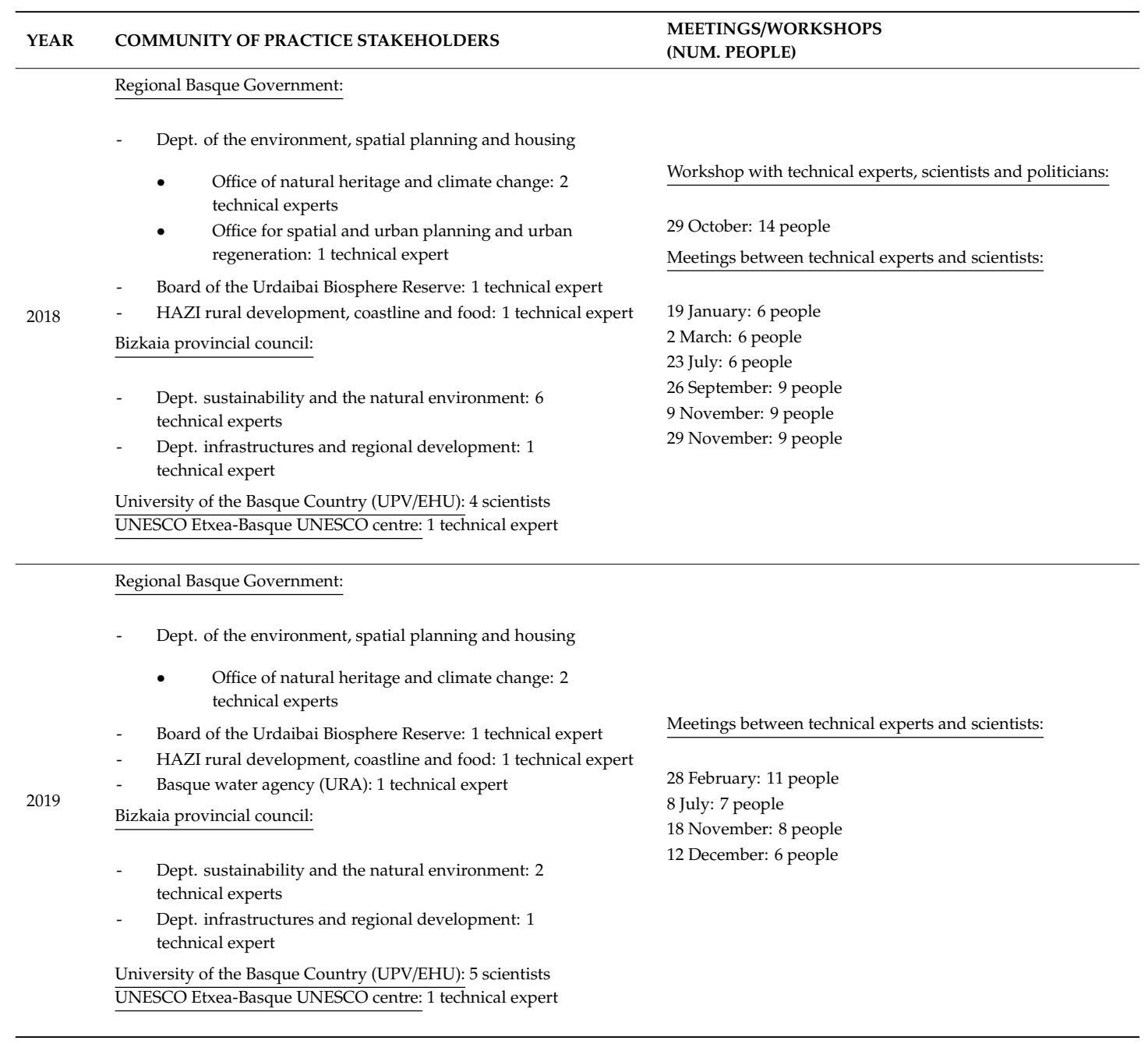

\section{Appendix B Statements about the Integration of ES into Spatial Planning Extracted from the SWOT Matrix and Assessed Through an Online Survey}

1. The use of methodologies linked to ecosystem services is an opportunity to recover biodiversity.

2. The support of international organisations and environmental regulation bodies contributes to the integration of ecosystem services into landscape management.

3. The conceptual framework of ecosystem services offers a comprehensive view of the region and facilitates optimal management of it.

4. Ecosystem services help assess environmental problems and how they can be compensated for.

5. The conceptual framework of ecosystem services establishes synergies between public administrations and social stakeholders.

6. There is little funding available for issues linked to ecosystem services.

7. There is a long history of processing environmental information, which may help facilitate the application of ecosystem services in landscape management.

8. It is a concept that the public finds familiar and easy to understand. The language is easy to understand for both the public and decision-makers.

9. There is a lack of practical instruments for implementing ecosystem services in landscape management, which makes it hard to do in day-to-day management.

10. Methodologies linked to ecosystem services strengthen nature-based solutions.

11. The lack of, or failure to comply with, international agreements may weaken the integration of ecosystem services into landscape management. 
12. The conceptual framework of ecosystem services is increasingly present in international regulations and documents.

13. The application of ecosystem services in landscape management helps foster R\&D.

14. Lack of knowledge regarding the methods used may generate mistrust in its working.

15. The existence of an increasing number of very active citizen platforms may facilitate the application of the ecosystem services outlook in landscape management.

16. Budgetary cutbacks may hamper the integration of ecosystem services into landscape management.

17. Processes such as globalisation and migrations from rural areas to cities result in a decrease in the public perception of environmental values.

18. Ecosystem services generate knowledge, which encourages people to attach greater value to the environment.

19. The use of ecosystem services in landscape management may cause people to overlook the intrinsic value of natural diversity.

20. It is difficult to adapt the concept of ecosystem services to the public discourse.

21. Ecosystem services are not a priority on the political agenda, due to a lack of awareness among political and economic authorities.

22. The language used in relation to ecosystem services is hard to understand, with an overly anthropocentric focus.

\section{References}

1. Steffen, W.; Grinevald, J.; Crutzen, P.; McNeill, J. The Anthropocene: Conceptual and historical perspectives. Philos. Trans. R. Soc. A Math. Phys. Eng. Sci. 2011, 369, 842-867. [CrossRef] [PubMed]

2. Duarte, C.M.; Alonso, S.; Benito, G.; Dachs, J.; Montes, C.; Pardo Buendía, M.; Ríos, A.F.; Simó, R.; Valladares, F. Cambio Global. Impacto de la Actividad Humana Sobre el Sistema Tierra; Colección divulgación 3: Madrid, Spain, 2006; p. 167. ISBN 978-84-00-08452-3.

3. Reyers, B.; Folke, C.; Moore, M.-L.; Biggs, R.; Galaz, V. Social-Ecological Systems Insights for Navigating the Dynamics of the Anthropocene. Annu. Rev. Environ. Resour. 2018, 43, 267-289. [CrossRef]

4. $\mathrm{Wu}, \mathrm{J}$. Landscape sustainability science: Ecosystem services and human well-being in changing landscapes. Landsc. Ecol. 2013, 28, 999-1023. [CrossRef]

5. Costanza, R.; D’Arge, R.; De Groot, R.; Farber, S.; Grasso, M.; Hannon, B.; Limburg, K.; Naeem, S.; O'Neill, R.V.; Paruelo, J.; et al. The value of the world's ecosystem services and natural capital. Nature 1997, 387, 253-260. [CrossRef]

6. MEA (Millenium Ecosystem Assessment). Ecosystem and Human Well-Being: Synthesis; Island Press: Washington, DC, USA, 2005.

7. Díaz, S.; Pascual, U.; Stenseke, M.; Martín-López, B.; Watson, R.T.; Molnár, Z.; Hill, R.; Chan, K.M.A.; Baste, I.A.; A Brauman, K.; et al. Assessing nature's contributions to people. Science 2018, 359, 270-272. [CrossRef]

8. Jorda-Capdevila, D.; Glenk, K.; Holstead, K. What defines ecosystem services-based approaches? In Water Ecosystem Services; Cambridge University Press (CUP): Cambridge, UK, 2015; pp. 3-14.

9. Beaumont, N.J.; Mongruel, R.; Hooper, T. Practical application of the Ecosystem Service Approach (ESA): Lessons learned and recommendations for the future. Int. J. Biodivers. Sci. Ecosyst. Serv. Manag. 2017, 13, 68-78. [CrossRef]

10. Reyers, B.; Nel, J.L.; O'Farrell, P.J.; Sitas, N.; Nel, D.C. Navigating complexity through knowledge coproduction: Mainstreaming ecosystem services into disaster risk reduction. Proc. Natl Acad. Sci. USA 2015, 112, 7362-7368. [CrossRef]

11. Carmen, E.; Watt, A.; Carvalho, L.; Dick, J.; Fazey, I.; Garcia-Blanco, G.; Grizzetti, B.; Hauck, J.; Izakovicova, Z.; Kopperoinen, L.; et al. Knowledge needs for the operationalisation of the concept of ecosystem services. Ecosyst. Serv. 2018, 29, 441-451. [CrossRef] 
12. European Commission. European Commission Communication from the Commission to the European Parliament; The Council, the European Economic and Social Committee and the Committee of the Regions: Green Infrastructure (GI)_Enhancing Europe's Natural Capital; European Commission: Brussels, Belgium, 2013.

13. Naumann, S.; McKenna, D.; Kaphengst, T.; Pieterse, M.; Rayment, M.D. Implementation and Cost Elements of Green Infrastructure Projects; Final report to the European Commission: Brussels, Belgium, 2011.

14. Davies, C.; Hansen, R.; Rall, E.; Pauleit, S.; Lafortezza, R.; De Bellis, Y.; Santos, A.; Tosics, I. Green Infrastructure Planning and Implementation-The Status of European Green Space Planning and Implementation Based on an Analysis of Selected European City-Regions. EU FP7 Project GREEN SURGE (ENV.2013.6.2-5-603567), Deliverable 5.1, 2015. Available online: https:/greensurge.eu/working-packages/wp5/files (accessed on 23 February 2020).

15. Schneider, F.; Giger, M.; Harari, N.; Moser, S.; Oberlack, C.; Providoli, I.; Schmid, L.; Tribaldos, T.; Zimmermann, A. Transdisciplinary co-production of knowledge and sustainability transformations: Three generic mechanisms of impact generation. Environ. Sci. Policy 2019, 102, 26-35. [CrossRef]

16. Schneider, F.; Fry, P.; Ledermann, T.; Rist, S. Social Learning Processes in Swiss Soil Protection-The "From Farmer-To Farmer" Project. Hum. Ecol. 2009, 37, 475-489. [CrossRef]

17. Wenger, E. Communities of Practice and Social Learning Systems. Organization 2000, 7, 225-246. [CrossRef]

18. Pahl-Wostl, C.; Craps, M.; Dewulf, A.; Mostert, E.; Tabara, D.; Taillieu, T. Social Learning and Water Resources Management. Ecol. Soc. 2007, 12, 5. [CrossRef]

19. Hegger, D.; Lamers, M.; Van Zeijl-Rozema, A.; Dieperink, C. Conceptualising joint knowledge production in regional climate change adaptation projects: Success conditions and levers for action. Environ. Sci. Policy 2012, 18, 52-65. [CrossRef]

20. Schusler, T.M.; Decker, D.J.; Pfeffer, M.J. Social learning for collaborative natural resource management. Soc. Nat. Resour. 2003, 15, 309-326. [CrossRef]

21. Medema, W.; Adamowski, J.; Orr, C.; Furber, A.; Wals, A.; Milot, N. Building a Foundation for Knowledge Co-Creation in Collaborative Water Governance: Dimensions of Stakeholder Networks Facilitated through Bridging Organizations. Water 2017, 9, 60. [CrossRef]

22. Cortinovis, C.; Geneletti, D. Ecosystem services in urban plans: What is there, and what is still needed for better decisions. Land Use Policy 2018, 70, 298-312. [CrossRef]

23. Rozas, D.; Fürst, C.; Geneletti, D.; Almendra, O. Integration of ecosystem services in strategic environmental assessment across spatial planning scales. Land Use Policy 2018, 71, 303-310. [CrossRef]

24. Basque Government. Habitat EUNIS Map. Available online: ftp://ftp.geo.euskadi.net/cartografia/ (accessed on 20 September 2019).

25. Palacios-Agúndez, I.; Fernández De Manuel, B.; Rodríguez-Loinaz, G.; Peña, L.; Ametzaga-Arregi, I.; Alday, J.G.; Casado-Arzuaga, I.; Madariaga, I.; Arana, X.; Onaindia, M. Integrating stakeholders' demands and scientific knowledge on ecosystem services in landscape planning. Landsc. Ecol. 2014, 29, 1423-1433. [CrossRef]

26. Palacios-Agúndez, I.; Peña, L.; Ametzaga, I.; Rodríguez-Loinaz, G.; Onaindia, M. Sustainable landscape management based on cultural ecosystem services. Chang. Adapt. Socio-Ecol. Syst. 2017, 3, 103-110. [CrossRef]

27. Tengö, M.; Hill, R.; Malmer, P.; Raymond, C.M.; Spierenburg, M.; Danielsen, F.; Elmqvist, T.; Folke, C. Weaving knowledge systems in IPBES, CBD and beyond-Lessons learned for sustainability. Curr. Opin. Environ. Sustain. 2017, 26, 17-25. [CrossRef]

28. Liquete, C.; Kleeschulte, S.; Dige, G.; Maes, J.; Grizzetti, B.; Olah, B.; Zulian, G. Mapping green infrastructure based on ecosystem services and ecological networks: A Pan-European case study. Environ. Sci. Policy 2015, 54, 268-280. [CrossRef]

29. Onaindia, M.; Peña, L.; Fernández De Manuel, B.; Rodríguez-Loinaz, G.; Madariaga, I.; Palacios-Agúndez, I.; Ametzaga-Arregi, I. Land use efficiency through analysis of agrological capacity and ecosystem services in an industrialized region (Biscay, Spain). Land Use Policy 2018, 78, 650-661. [CrossRef]

30. Peña, L.; Onaindia, M.; Fernández De Manuel, B.; Ametzaga-Arregi, I.; Casado-Arzuaga, I. Analysing the Synergies and Trade-offs between Ecosystem Services to Reorient Land Use Planning in Metropolitan Bilbao (Northern Spain). Sustainability 2018, 10, 4376. [CrossRef] 
31. Rodríguez-Loinaz, G.; Peña, L.; Palacios-Agúndez, I.; Ametzaga, I.; Onaindia, M.; Ametzaga-Arregi, I. Identifying Green Infrastructure as a Basis for an Incentive Mechanism at the Municipality Level in Biscay (Basque Country). Forests 2018, 9, 22. [CrossRef]

32. ESRI. ArcMap 10.3. Redlands; Environmental Systems Research Institute: Redlands, CA, USA, 2016.

33. Reyers, B.; O'Farrell, P.J.; Cowling, R.M.; Egoh, B.N.; Le Maitre, D.C.; Vlok, J.H.J. Ecosystem Services, Land-Cover Change, and Stakeholders: Finding a Sustainable Foothold for a Semiarid Biodiversity Hotspot. Ecol. Soc. 2009, 14, 38. [CrossRef]

34. O'Farrell, P.J.; Reyers, B.; Le Maitre, D.C.; Milton, S.; Egoh, B.; Maherry, A.; Colvin, C.; Atkinson, D.; De Lange, W.; Blignaut, J.; et al. Multi-functional landscapes in semi arid environments: Implications for biodiversity and ecosystem services. Landsc. Ecol. 2010, 25, 1231-1246. [CrossRef]

35. Rodríguez-Loinaz, G.; Alday, J.G.; Onaindia, M. Multiple ecosystem services landscape index: A tool for multifunctional landscapes conservation. J. Environ. Manag. 2015, 147, 152-163. [CrossRef]

36. UNESCO Chair on Sustainable Development and Environmental Education (UPV/EHU). Available online: http://www.ehu.eus/cdsea/web/index.php/investigacion/servicios-ecosistema-euskadi/objetivos/ (accessed on 20 January 2020).

37. Eusko Jaurlaritza/Gobierno Vasco. geoEuskadi. Available online: https://www.geo.euskadi.eus/s69-bisorea/ es/x72aGeoeuskadiWAR/index.jsp;ftp://ftp.geo.euskadi.eus/cartografia/Medio_Ambiente/Servicios_ Ecosistemas/ (accessed on 20 January 2020).

38. Castillo-Eguskitza, N.; Martín-López, B.; Onaindia, M. A comprehensive assessment of ecosystem services: Integrating supply, demand and interest in the Urdaibai Biosphere Reserve. Ecol. Indic. 2018, 93, 1176-1189. [CrossRef]

39. Onaindia, M.; Fernández De Manuel, B.; Madariaga, I.; Rodríguez-Loinaz, G. Co-benefits and trade-offs between biodiversity, carbon storage and water flow regulation. For. Ecol. Manag. 2013, 289, 1-9. [CrossRef]

40. Eusko Jaurlaritza/Gobierno Vasco. Available online: https://www.euskadi.eus/documentacion/2016/planrector-de-uso-y-gestion-prug-de-la-reserva-de-la-biosfera-de-urdaibai/web01-a2ingurd/es/ (accessed on 12 December 2019).

41. Bizkaiko Foru Aldundia/Diputación Foral de Bizkaia. Available online: https://www.bizkaia.eus/home2/ Temas/DetalleTema.asp?Tem_Codigo=10554\&Idioma=CA\&dpto_biz=6\&codpath_biz=6\%7C8366\% 7C10128\%7C10133\%7C10131\%7C10532 (accessed on 12 December 2019).

42. Eusko Jaurlaritza/Gobierno Vasco. Available online: https://www.euskadi.eus/directrices-de-ordenacionterritorial-dot/web01-a2lurral/es/ (accessed on 12 December 2019).

43. Burkhard, B.; Maes, J. Mapping Ecosystem Services; Pensoft Publishers: Sofia, Bulgaria, 2017; p. 374, ISBN 978-954-642-829-5.

44. Fürst, C.; Luque, S.; Geneletti, D. Nexus thinking-How ecosystem services can contribute to enhancing the cross-scale and cross-sectoral coherence between land use, spatial planning and policy-making. Int. J. Biodivers. Sci. Ecosyst. Serv. Manag. 2017, 13, 412-421. [CrossRef]

45. Spyra, M.; Kleemann, J.; Cetin, N.I.; Navarrete, C.J.V.; Albert, C.; Palacios-Agúndez, I.; Ametzaga-Arregi, I.; La Rosa, D.; Rozas-Vásquez, D.; Esmail, B.A.; et al. The ecosystem services concept: A new Esperanto to facilitate participatory planning processes? Landsc. Ecol. 2018, 34, 1715-1735. [CrossRef]

46. Barbati, A.; Corona, P.; Salvati, L.; Gasparella, L. Natural forest expansion into suburban countryside: Gained ground for a green infrastructure? Urban For. Urban Green. 2013, 12, 36-43. [CrossRef]

47. Rozas-Vásquez, D.; Fürst, C.; Geneletti, D.; Muñoz, F. Multi-actor involvement for integrating ecosystem services in strategic environmental assessment of spatial plans. Environ. Impact Assess. Rev. 2017, 62, 135-146. [CrossRef]

48. Díaz, S.; Demissew, S.; Carabias, J.; Joly, C.; Lonsdale, M.; Ash, N.; Larigauderie, A.; Adhikari, J.R.; Aricò, S.; Báldi, A.; et al. The IPBES Conceptual Framework-Connecting nature and people. Curr. Opin. Environ. Sustain. 2015, 14, 1-16. [CrossRef]

49. Galvin, K.A.; Reid, R.S.; E Fernández-Giménez, M.; Kaelo, D.O.; Baival, B.; Krebs, M. Co-design of transformative research for rangeland sustainability. Curr. Opin. Environ. Sustain. 2016, 20, 8-14. [CrossRef]

50. Pascual, U.; Balvanera, P.; Díaz, S.; Pataki, G.; Roth, E.; Stenseke, M.; Watson, R.T.; Dessane, E.B.; Islar, M.; Kelemen, E.; et al. Valuing nature's contributions to people: The IPBES approach. Curr. Opin. Environ. Sustain. 2017, 26, 7-16. [CrossRef] 
51. Deal, R.; Fong, L.; Phelps, E. Integrating Ecosystem Services into National Forest Service Policy and Operations; Gen. Tech. Rep. PNW-GTR-943; US Department of Agriculture, Forest Service, Pacific Northwest Research Station: Portland, OR, USA, 2017; Volume 87, p. 943.

52. Harrison-Atlas, D.; Theobald, D.M.; Goldstein, J.H. A systematic review of approaches to quantify hydrologic ecosystem services to inform decision-making. Int. J. Biodivers. Sci. Ecosyst. Serv. Manag. 2016, 12, 160-171. [CrossRef]

53. Başkent, E.Z. A Framework for Characterizing and Regulating Ecosystem Services in a Management Planning Context. Forests 2020, 11, 102. [CrossRef]

54. Kates, R.W. From the Unity of Nature to Sustainability Science: Ideas and Practice; Center for International Development Working; Harvard University: Cambridge, MA, UK, 2011; p. 218.

55. Bettencourt, L.M.A.; Kaur, J. Evolution and structure of sustainability science. Proc. Natl. Acad. Sci. USA 2011, 108, 19540-19545. [CrossRef]

56. Miller, T.R.; Wiek, A.; Sarewitz, D.; Robinson, J.; Olsson, L.; Kriebel, D.; Loorbach, D. The future of sustainability science: A solutions-oriented research agenda. Sustain. Sci. 2014, 9, 239-246. [CrossRef]

57. Wiek, A.; Lang, D.J. Transformational Sustainability Research Methodology. In Sustainability Science; Heinrichs, H., Martens, P., Michelsen, G., Wiek, A., Eds.; Springer: Dordrecht, The Netherlands, 2016.

58. Berkes, F.; Folke, C. Linking Social and Ecological Systems. Management Practices and Social Mechanisms for Building Resilience; Cambridge University Press: New York, NY, USA, 1998.

59. Keeler, B.L.; Chaplin-Kramer, R.; Guerry, A.D.; Addison, P.F.E.; Bettigole, C.; Burke, I.C.; Gentry, B.; Chambliss, L.; Young, C.; Travis, A.J.; et al. Society Is Ready for a New Kind of Science-Is Academia? BioScience 2017, 67, 591-592. [CrossRef]

(C) 2020 by the authors. Licensee MDPI, Basel, Switzerland. This article is an open access article distributed under the terms and conditions of the Creative Commons Attribution (CC BY) license (http://creativecommons.org/licenses/by/4.0/). 